\title{
SISTEM INFORMASI PERSEDIAAN DONOR DARAH BERBASIS SUPPLY CHAIN MANAGEMENT DI PALANG MERAH INDONESIA (PMI) MEDAN
}

\author{
Rut Natalina Nababan ${ }^{1}$, Humuntal Rumapea ${ }^{2}$, Indra M. Sarkis ${ }^{3}$ \\ ${ }^{123}$ Sistem Informasi, Fakultas Ilmu Komputer, Universitas Methodist Indonesia \\ Jl. Hang Tuah No.8 Medan 20152 \\ nababanruth@gmail.com ${ }^{1}$, humuntalrumapea@gmail.com ${ }^{2}$, poetramora@gmail.com ${ }^{3}$
}

\begin{abstract}
Palang Merah Indonesia (PMI) is an independent and neutral organization in Indonesia whose activities are in the social field of humanity. PMI Medan City is overwhelmed by managing data on blood receipts from various places, this causes delays in information that should be informed to the public, the delay in disseminating information about blood stocks can have an impact on the difficulty of getting information on certain types of blood needs. The blood supply in PMI will later be distributed to the hospital. Many hospitals often have difficulty getting information or lack of public knowledge about how to obtain information about the availability of blood stock at PMI. Therefore we need an information system that can provide information quickly, well and accurately. To overcome this, a system will be developed that uses the concept of Supply Chain Management to control the blood supply in PMI. This system can control the blood donation process both during donation, the donation process, and finally for whom the blood is donated so that the blood stock information process can be maintained and will not lack.
\end{abstract}

Keywords: Supply Chain Management, Control Stock, PMI.

\section{PENDAHULUAN}

Palang Merah Indonesia (PMI) adalah sebuah organisasi independen dan netral di Indonesia yang kegiatannya di bidang sosial kemanusiaan. Dalam melaksanakan seluruh aktifitasnya PMI selalu berpegang teguh pada tujuh prinsip Palang Merah dan Bulan sabit merah Internasional yaitu kemanusiaan, kesukarelaan, kenetralan, kesamaan, kemandirian, kesatuan, dan kesemestaan. Palang Merah Indonesia tidak berpihak pada golongan politik, ras, suku ataupun agama tertentu. Palang Merah Indonesia dalam pelaksanaannya juga tidak melakukan pembedaan tetapi mengutamakan objek korban yang paling membutuhkan pertolongan segera untuk keselamatan jiwanya.

Dalam perjalanannya Palang Merah Kota Medan bergerak dalam bidang donor darah atau konseling darah, pemeriksaan kesehatan donor darah dan pendistribusian kantong darah bagi yang membutuhkan. PMI Kota Medan kewalahan mengelola data penerimaan darah dari berbagai tempat hal ini menyebabkan terhambatnya informasi yang semestinya dapat diinformasikan kepada masyarakat, keterlambatan penyebaran informasi mengenai stok darah dapat berimbas pada sulitnya masyarakat memperoleh informasi kebutuhan darah golongan tertentu. Stok darah yang ada di PMI ini nantinya akan didistribusikan ke rumah sakit. Banyak Rumah Sakit sering kesulitan mendapatkan informasi atau kurangnya pengetahuan masyarakat mengenai cara mendapatkan informasi mengenai ketersediaan stok darah di PMI.

Oleh sebab itu diperlukan adanya sistem informasi yang dapat menyediakan informasi dengan cepat, baik dan akurat. Kebutuhan ini perlu ditunjang dengan alat penyimpanan data, seperti komputer (Hardware), perangkat lunak (Software), serta sumber daya manusia (Brainware). Sehingga diharapkan dapat membantu dalam penyajian informasi bagi pimpinan atau pihak-pihak yang memerlukan informasi tentang data donor. Untuk mengatasi hal tersebut nantinya akan dibuat sebuah sistem yang menggunakan konsep Supply Chain Management untuk mengontrol persediaan darah yang ada di PMI. Sistem ini dapat mengontrol proses donor darah baik itu saat pendonoran, proses pendonoran, dan terakhir untuk siapa darah tersebut didonorkan sehingga proses informasi stok darah dapat terjaga dan tidak akan kekurangan.

Atas dasar itu Penulis tertarik untuk membuat Sistem Informasi Pengelolaan Transfusi Darah di PMI Unit Transfusi Darah Cabang Medan. Sehingga skripsi yang akan Penulis sampaikan adalah mengenai "Sistem Informasi Persediaan Donor Darah Berbasis Supply Chain Management di PMI Medan”.

\section{LANDASAN TEORI}

A. Defenisi Supply Chain Management (SCM)

Supply Chain Management merupakan metode, alat atau pendekatan pengelolaan yang melibatkan perusahaan - perusahaan yang terlibat dalam memasok bahan baku, memproduksi barang, maupun mengirimkannya ke final consumer. Supply chain management tidak hanya berorientasi pada urusan internal, melainkan juga urusan eksternal yang menyangkut hubungan dengan perusahaan - perusahaan partner.

Supply Chain Management berbicara mengenai bagaimana mengatur pemasokan barang terhadap perusahaan. Namun SCM bukan hanya berbicara mengenai pemasokan barang secara sederhana. SCM berbicara mengenai cara untuk mengintegrasikan rantai pasokan barang sampai pendistribusian barang ketangan pelanggan akhir. Hal ini merupakan sesuatu yang sangat kompleks, karena begitu banyak pihak yang terlibat dalam perjalanan dari supplier, perusahaan, distributor sampai ke pengguna akhir. 


\section{B. Komponen SCM}

komponen supply chain management terdiri dari

3 komponen utama, yaitu :

\section{Upstream Supply Chain}

Bagian ini meliputi supplier tingkat pertama (dapat berupa manufaktur atau perakitan) beserta supplier mereka. Hubungan ini dapat diperluas meliputi beberapa perusahaan hingga ke supplier material asli (seperti barang tambang, hasil panen).

\section{Internal Supply Chain}

Bagian ini meliputi semua proses yang digunakan perusahaan dalam mengubah input dari supplier menjadi output, sejak bahan baku masuk ke perusahaan sehingga menjadi barang jadi dan didistribusikan ke luar perusahaan.

\section{Downstream Supply Chain}

Bagian ini meliputi semua proses yang terdapat dalam pendistribusian dan pengiriman produk ke konsumen akhir. Secara lebih jauh, supply chain berakhir ketika produk tidak lagi digunakan konsumen setelah diterima oleh konsumen. Aktifitas segmen ini meliputi beberapa pihak distributor (agen dan pengecer)

(Desi Ariani \& Bambang Munas Dwiyanto , 2013)

\section{Konsep Kerja SCM}

Supply chain dapat didefinisikan sebagai sekumpulan aktifitas (dalam bentuk entitas/fasilitas) yang terlibat dalam proses transformasi dan distribusi barang mulai dari bahan baku paling awal dari alam sampai produk jadi pada konsumen akhir. Menyimak dari definisi ini, maka suatu supply chain terdiri dari perusahaan yang mengangkut bahan baku dari bumi/alam, perusahaan yang mentransformasikan bahan baku menjadi bahan setengah jadi atau komponen, supplier bahan-bahan pendukung produk, perusahaan perakitan, distributor, dan retailer yang menjual barang tersebut ke konsumen akhir.

\section{ANALISA DAN PERANCANGAN SYSTEM}

\section{A. Analisa Sistem}

Analisis sistem merupakan tahap yang bertujuan untuk memahami sistem, mengetahui kekurangan sistem dan menentukan kebutuhan sistem pemesanan. Dengan menganalisis prosedur yang sedang berjalan, maka sistem tersebut dapat di evaluasi sehingga dapat dibuat satu usulan untuk sistem yang baru dari hasil evaluasi sistem tersebut.

B. Analisis Prosedur yang Sedang Berjalan

1. Prosedur Donor Darah Yang Sedang Berjalan Setelah melakukan pengamatan langsung pada PMI Kota Medan tentang prosedur donor darah yang sedang berjalan adalah sebagai berikut :

a. Pendonor datang ke tempat donor darah yang sudah disediakan oleh PMI Kota Medan.

b. Pendonor mengisi data - data diri kemudian data tersebut diberikan kepada admin.

c. Petugas medis memeriksa kondisi pendonor, apabila kondisi pendonor baik maka proses donor darah dilanjutkan. d. Petugas medis memeriksa dan mengambil darah pendonor, kemudian hasil yang diambil akan dicatat oleh admin untuk kelengkapan data darah yang masuk.

e. Hasil pencatatan darah yang masuk tersebut akan dilaporkan kepada admin untuk dicatat sebagai kelengkapan laporan apabila suatu saat diperlukan.

Prosedur yang berjalan di atas dapat digambarkan pada flowmap di bawah ini:

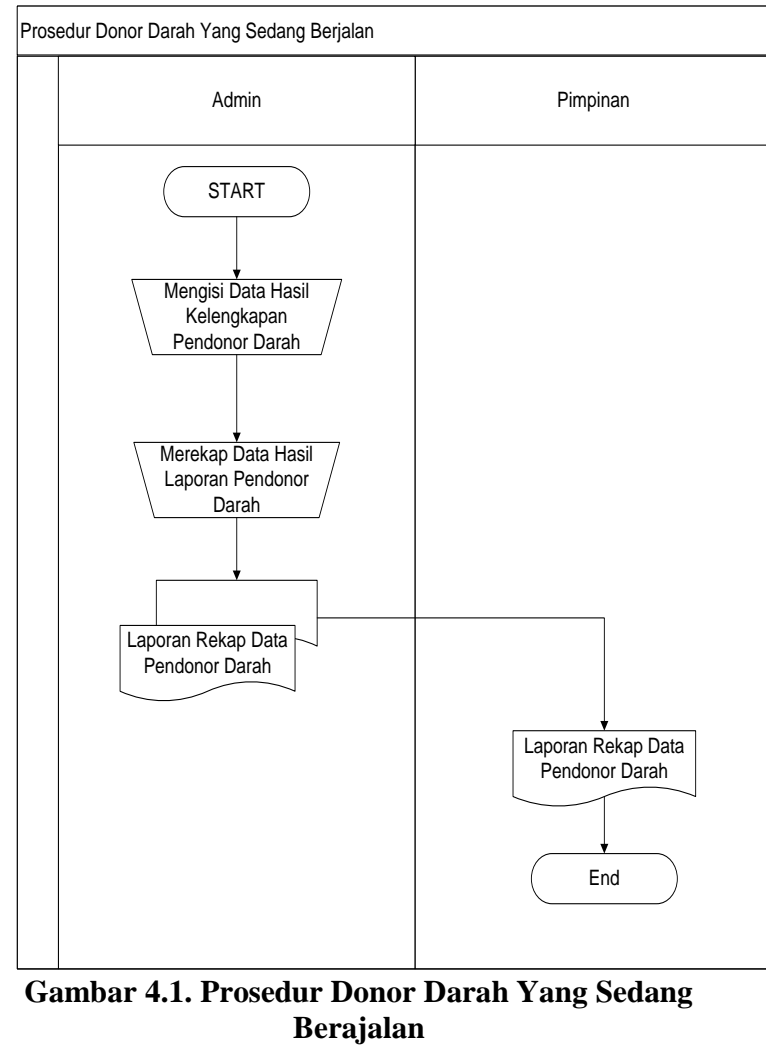

C. Perancangan Sistem Yang Diusulkan

Berdasarkan hasil analisis desain perancangan, maka dirancang sistem sebagai berikut :

a. Perancangan Diagram Konteks yang akan dibuat pada perancangan sistem yang akan dibangun dapat dilihat pada gambar 4.2 di bawah ini.

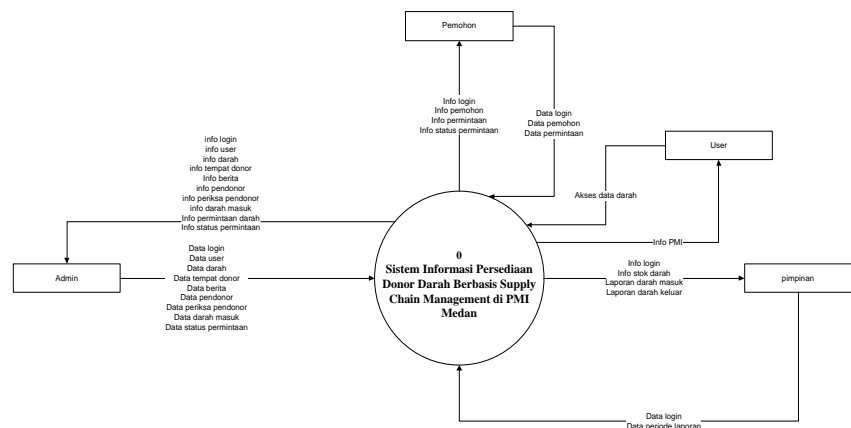

Gambar 4.2 Diagram Konteks Yang Diusulkan

D. Data Flow Diagram (DFD) 
DFD Level 1 merupakan penjabaran dari proses Diagram Konteks. Berikut ini adalah gambar DFD level 0 dan DFD level 1 yang telah dibangun seperti yang terlihat pada 4.3 dibawah ini :

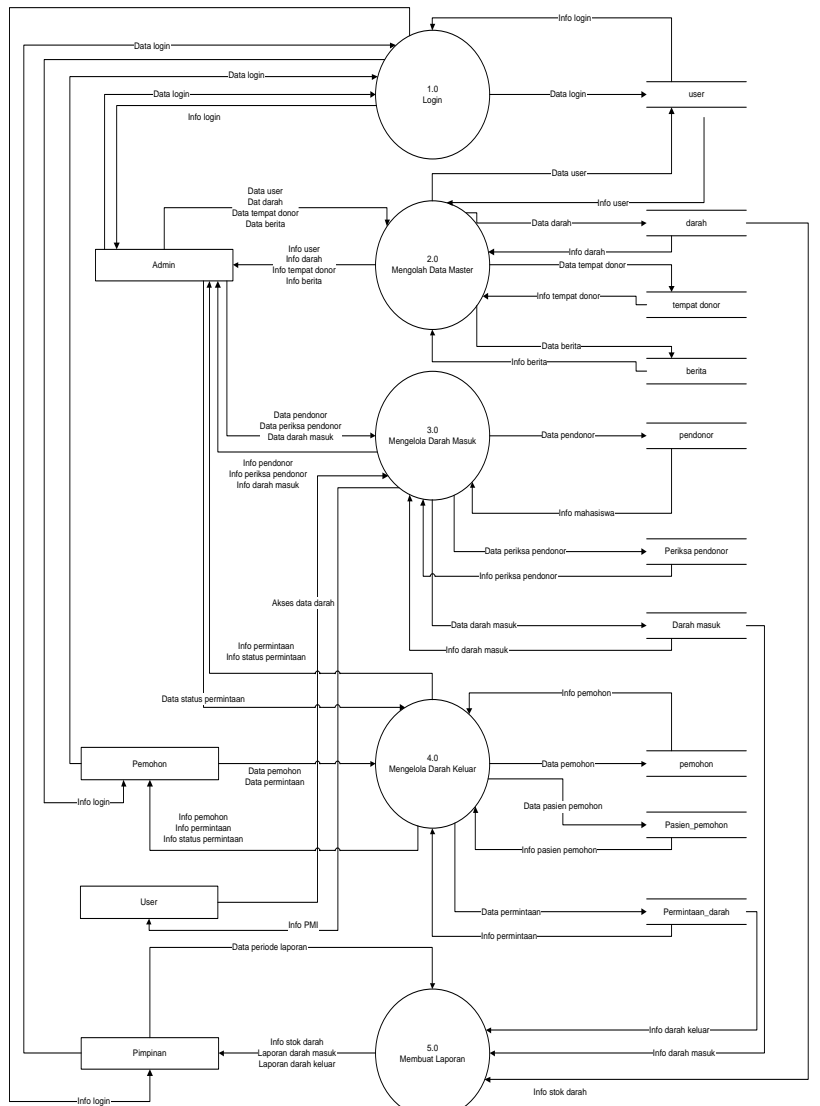

Gambar 4.3.DFD Level 0

\section{PEMBAHASAN}

\section{A. Pengertian Implementasi Sistem}

Implementasi Sistem adalah langkah-langkah atau prosedur yang dilakukan dalam menyelesaikan desain sistem yang telah disetujui, menguji, dan memulai sistem baru yang telah disempurnakan.

B. Komponen Utama dalam Implementasi Sistem Agar sistem perancangan yang telah dikerjakan dapat berjalan baik atau tidak, maka perlu kiranya dilakukan pengujian terhadap sistem yang telah dikerjakan. Oleh karena itu, dibutuhkan beberapa komponen untuk mencakup perangkat keras (Hardware), perangkat lunak (software), dan manusia (Brainware).

\section{Tampilan Program}

Subbab ini akan menunjukkan tampilan program dan desain program website dari hasil perancangan yang telah dibangun pada bab sebelumnya.

\section{Tampilan Utama Login User}

Form di bawah ini adalah form yang berfungsi sebagai user baik admin dan pimpinan yang ingin masuk ke halaman akun mereka. Seorang admin dan pimpinan yang ingin masuk harus diwajibkan memberikan username dan password yang benar.

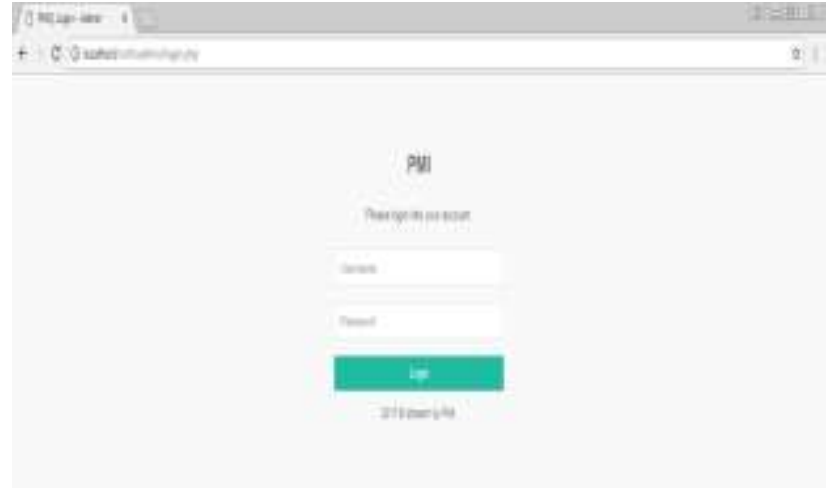

\section{Gambar 5.1 Tampilan Halaman Login User}

2. a. Tampilan Halaman Input Data User

Gambar di bawah ini merupakan tampilan gambar untuk Input data User. Gambar Input Data User dapat dilihat pada gambar 5.2.

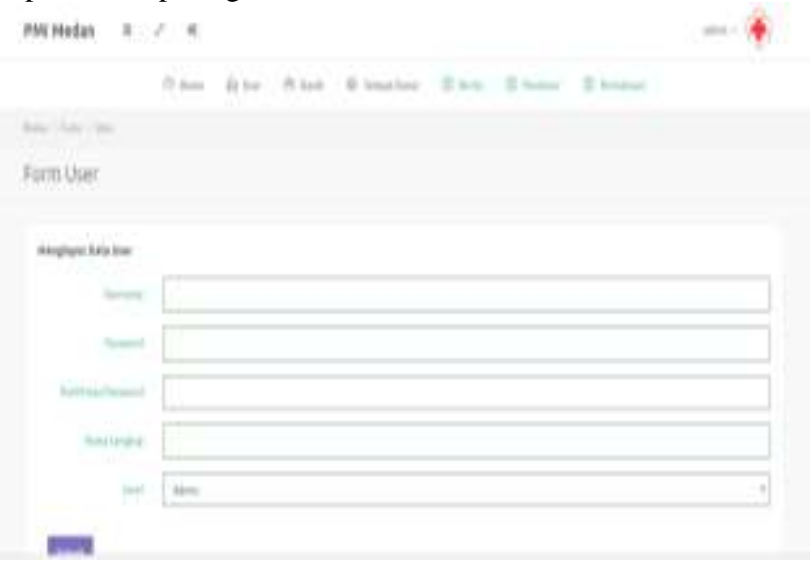

Gambar 5.2. Tampilan Halaman Input Data User

b. Tampilan Halaman Output Data User

Di bawah ini menampilkan data user. Tampilan data user dapat dilihat pada gambar 5.3.

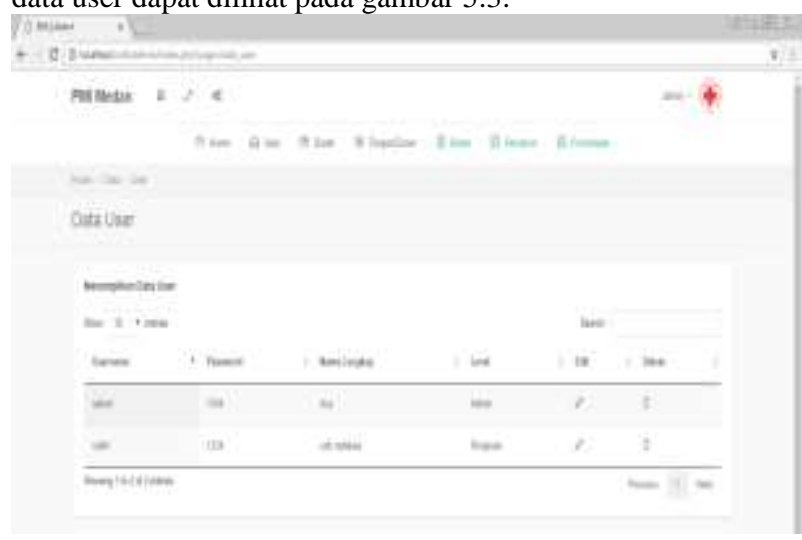

Gambar 5.3 Tampilan Halaman Output Data User

3. a. Tampilan Halaman Input Data Darah

Gambar di bawah ini merupakan tampilan gambar untuk input data darah. Gambar input data darah dapat dilihat pada gambar 5.4 . 


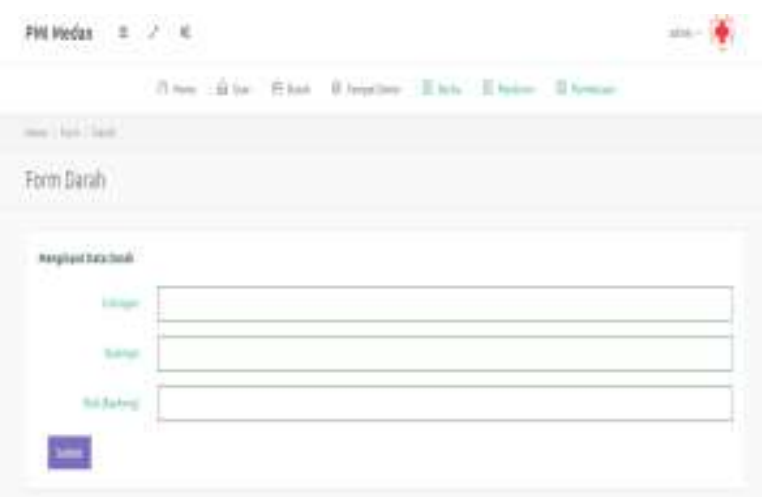

Gambar 5.4 Tampilan Halaman Input Data Darah

\section{b. Tampilan Halaman Output Data Darah}

Di bawah ini menampilkan data darah. Tampilan data user dapat dilihat pada gambar 5.5.

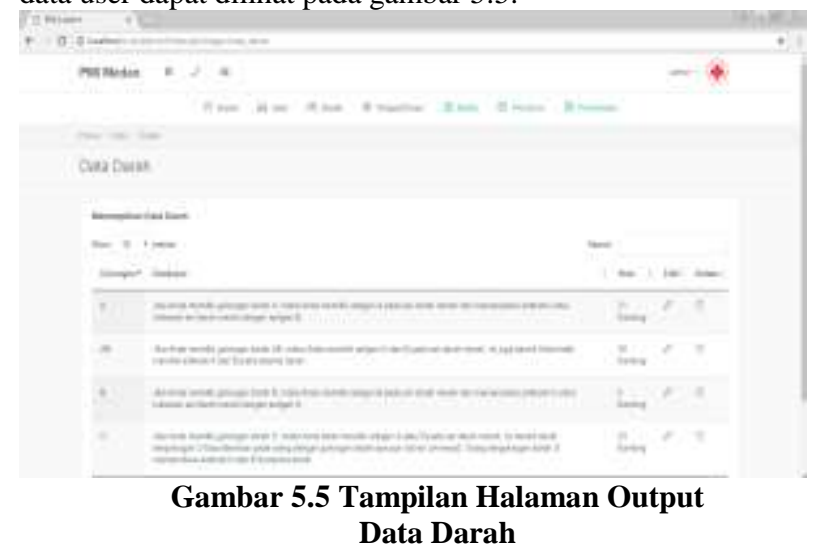

4. a. Tampilan Halaman Input Data Tempat Donor

Gambar di bawah ini merupakan tampilan gambar untuk input data tempat donor.

$$
\text { awhoin }>>\text { c }
$$

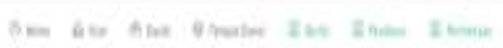

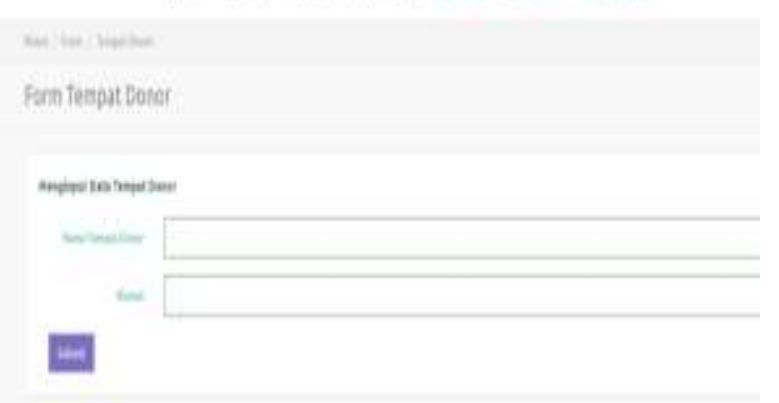

\section{Gambar 5.6 Tampilan Halaman Input Data} Tempat Donor

\section{b. Tampilan Halaman Output Data Tempat Donor}

Di bawah ini menampilkan data tempat donor.

Tampilan data tempat donor dapat dilihat pada gambar 5.7.

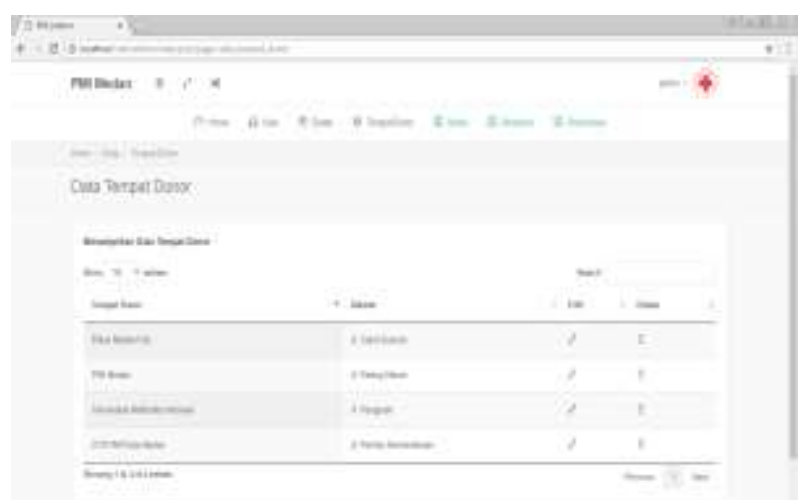

Gambar 5.7 Tampilan Halaman Output Data Tempat Donor

5. a. Tampilan Halaman Input Berita

Gambar di bawah ini merupakan tampilan gambar untuk input data berita.

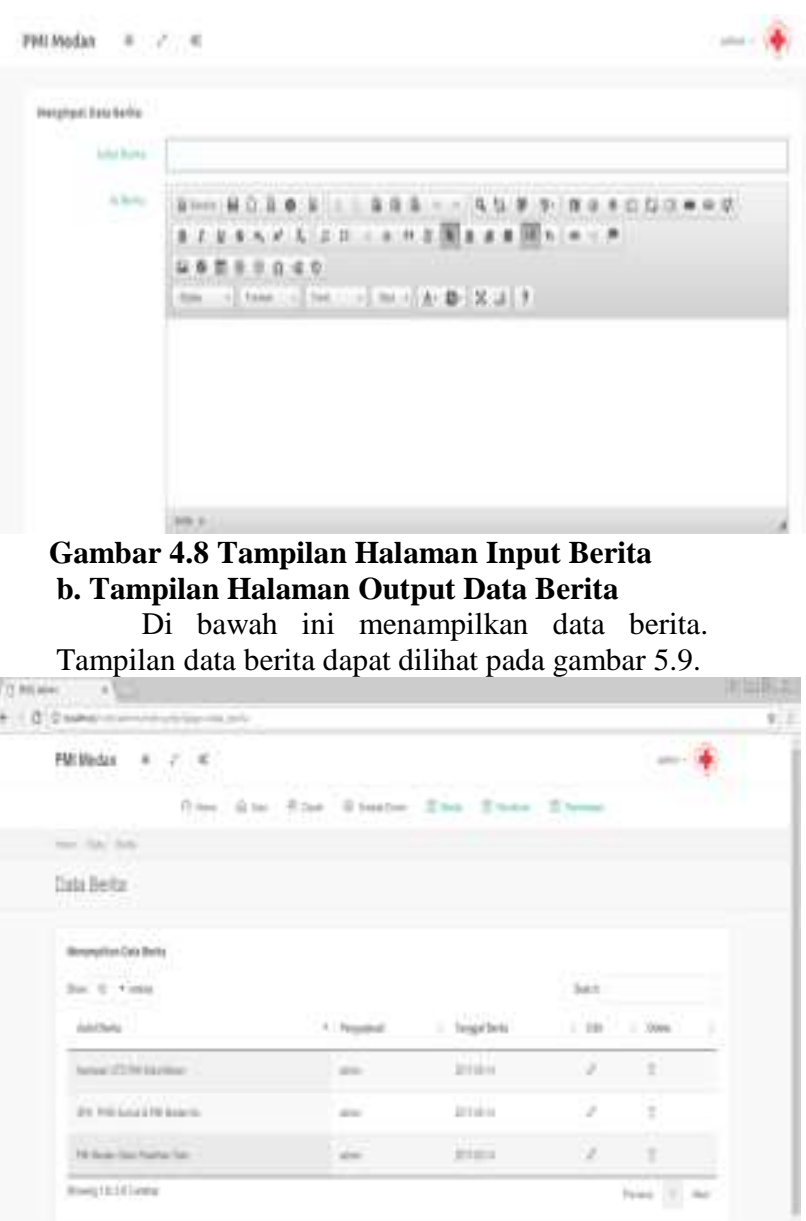

Gambar 4.9 Tampilan Halaman Input Berita 6. a. Tampilan Halaman Input Pendonor Darah

Gambar di bawah ini merupakan tampilan gambar untuk input data pendonor darah. 


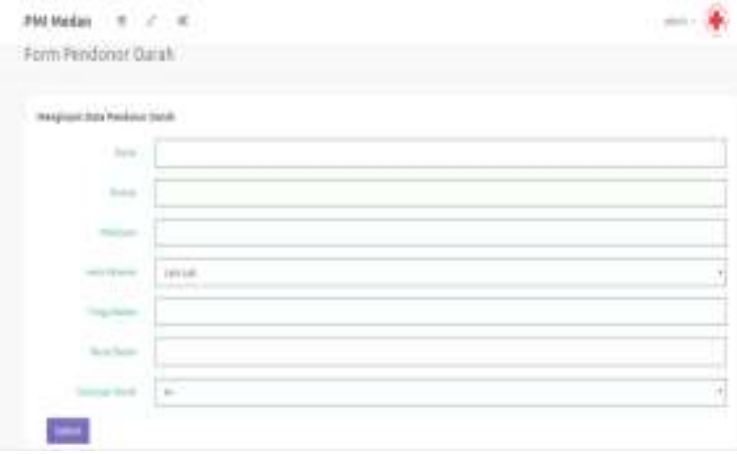

Gambar 4.10 Tampilan Halaman Input Pendonor Darah

\section{b. Tampilan Halaman Input Periksa Pendonor}

Gambar di bawah ini merupakan tampilan gambar untuk input data periksa pendonor.

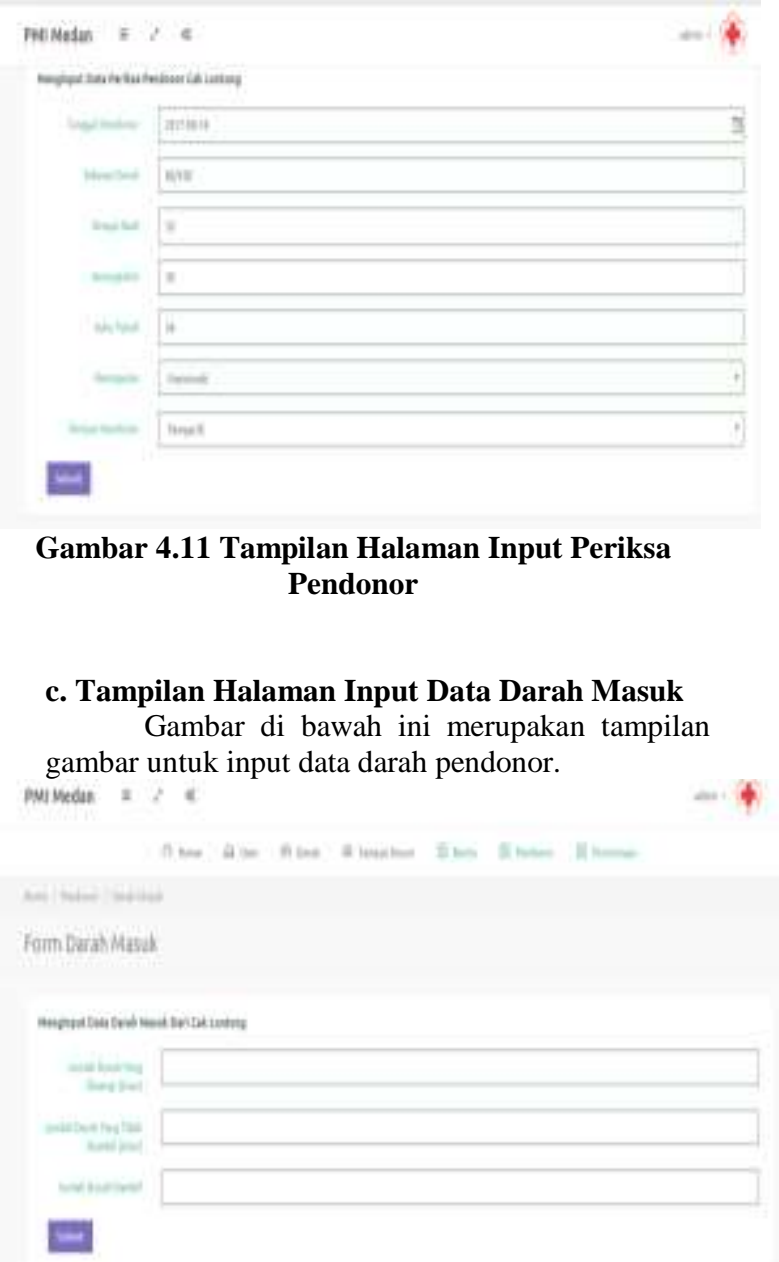

Gambar 4.12 Tampilan Halaman Input Data Darah Masuk

\section{d. Tampilan Halaman Output Data Pendonor}

Di bawah ini menampilkan data pendonor.

Tampilan data pendonor dapat dilihat pada gambar 5.13.

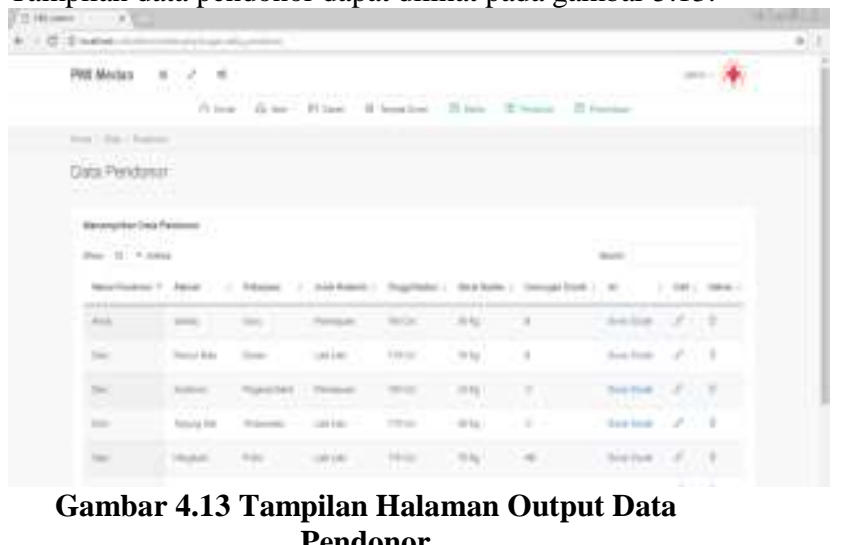

$$
\text { Pendonor }
$$

7. a. Tampilan Halaman Input Register Pemohon

Gambar di bawah ini merupakan tampilan gambar untuk input data register pemohon.

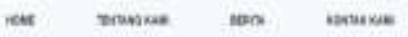

AEGISTER PEHOHON

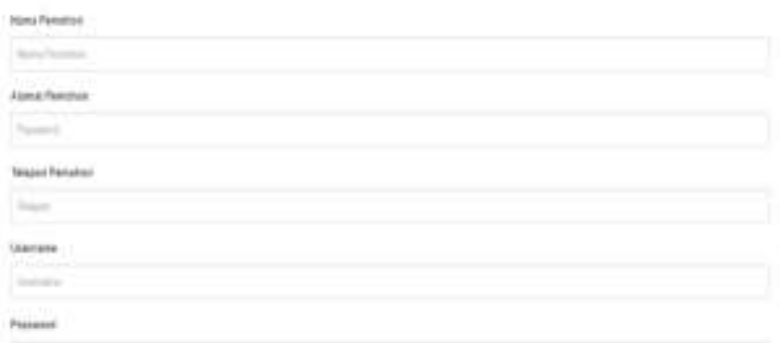

Gambar 5.14 Tampilan Halaman Input Register Pemohon

\section{b. Tampilan Halaman Login Pemohon}

Form di bawah ini adalah form yang berfungsi sebagai pemohon yg ingin masuk ke halaman akun. Pemohon harus memberikan username dan password yang valid.

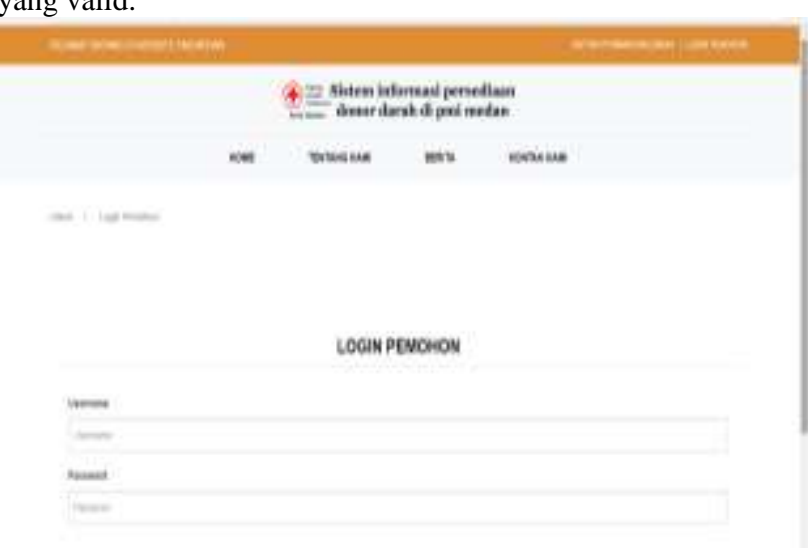

Gambar 4.15 Tampilan Halaman Login Pemohon

c. Tampilan Halaman Output Data Pemohon

Di bawah ini menampilkan data pemohon.

Tampilan data pemohon dapat dilihat pada gambar 5.16. 


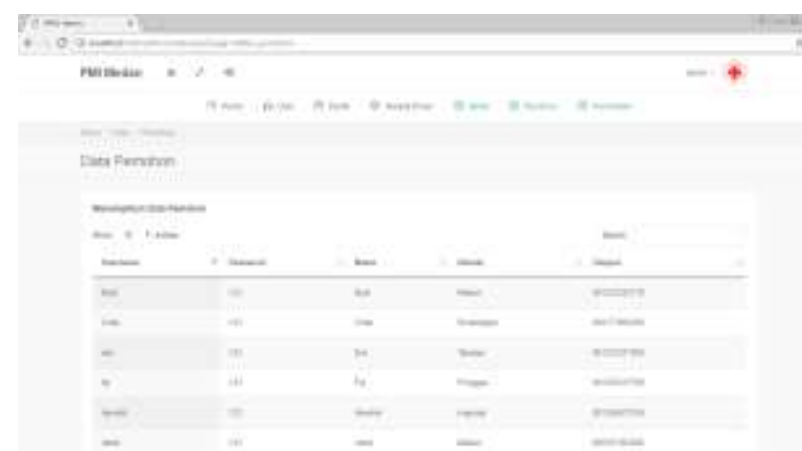

Gambar 4.16 Tampilan Halaman Output Data Pemohon

\section{8. a.Tampilan Halaman Input Pasien Pemohon}

Gambar di bawah ini merupakan tampilan gambar untuk input data pasien pemohon.

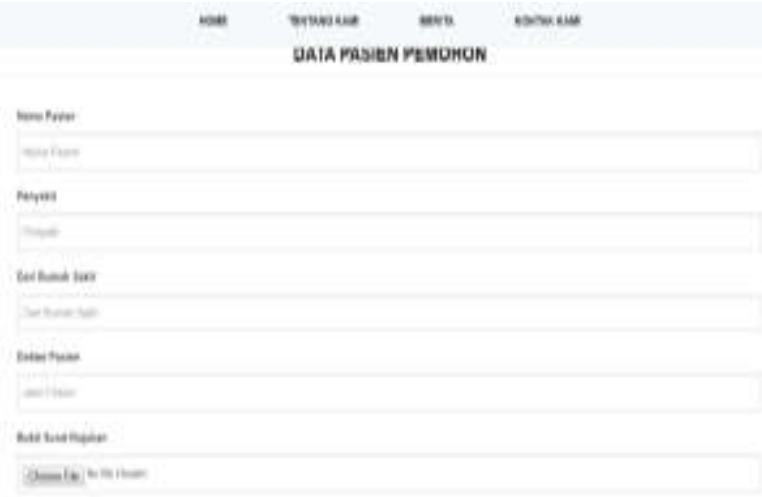

Gambar 5.17 Tampilan Halaman Input Pasien Pemohon

\section{b. Tampilan Halaman Input Permintaan Darah}

Gambar di bawah ini merupakan tampilan gambar untuk input data permintaan darah.
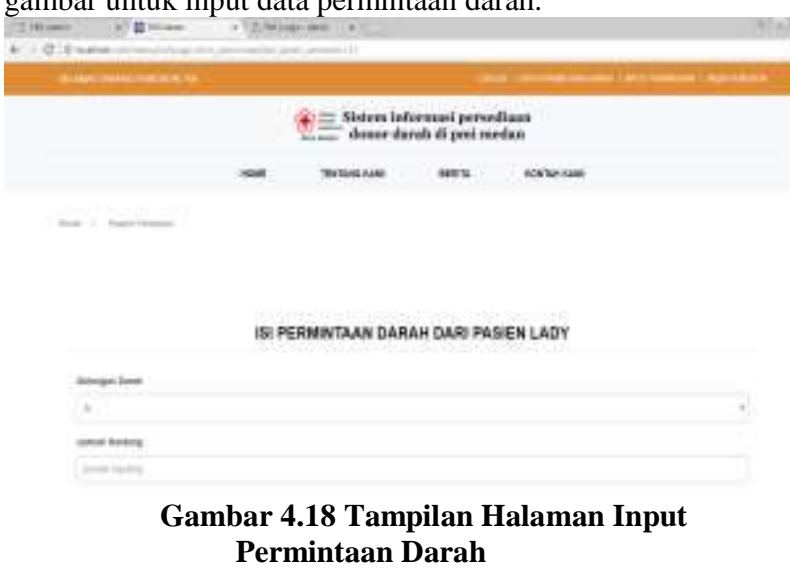

\section{9. a. Tampilan Data Permintaan Darah Yang Belom} Dikonfirmasi

Gambar dibawah ini merupakan tampilan dari data permintaan darah yang belum dikonfirmasi oleh admin atau pimpinan.

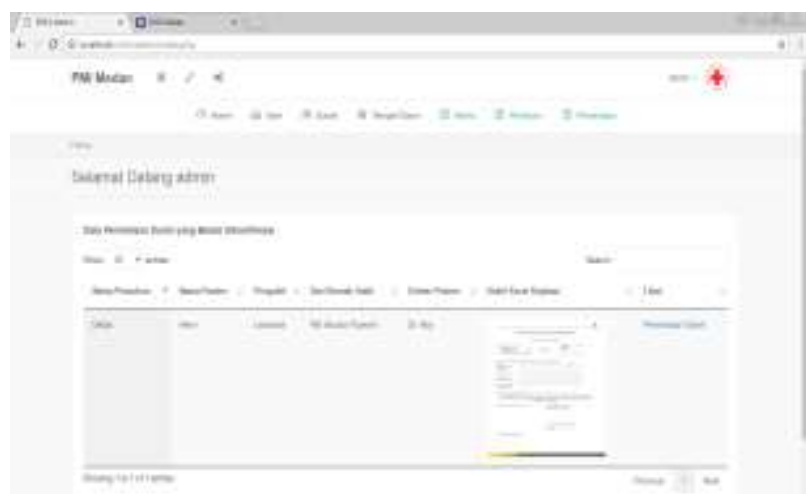

Gambar 5.19 Tampilan Data Permintaan Darah Yang Belom Dikonfirmasi

\section{b. Tampilan Data Permintaan Darah Yang Sudah Disetujui}

Gambar dibawah ini merupakan tampilan dari data permintaan darah yang sudah disetujui oleh admin atau pimpinan.

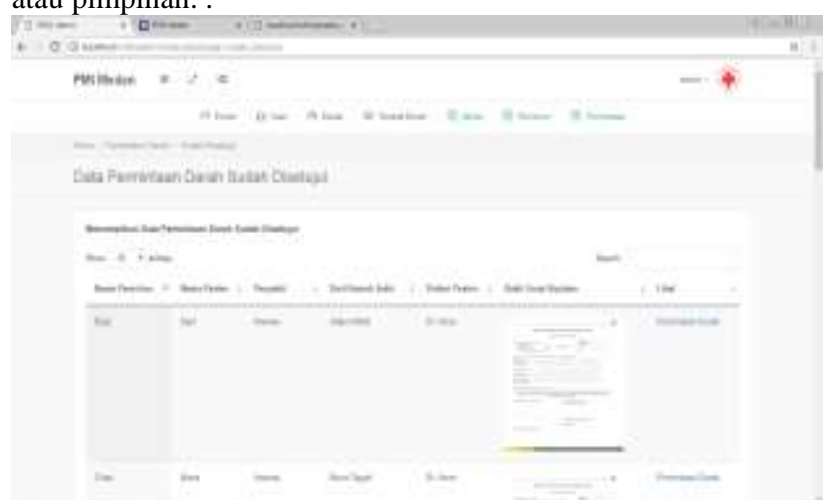

\section{Gambar 4.20 Tampilan Data Permintaan Darah} Yang Sudah Disetujui

\section{Laporan Darah Masuk Berdasarkan Periode} Gambar di bawah ini menampilkan laporan darah masuk berdasarkan periode tertentu. Gambar laporan darah masuk berdasarkan periode dapat dilihat pada gambar dibawah ini.

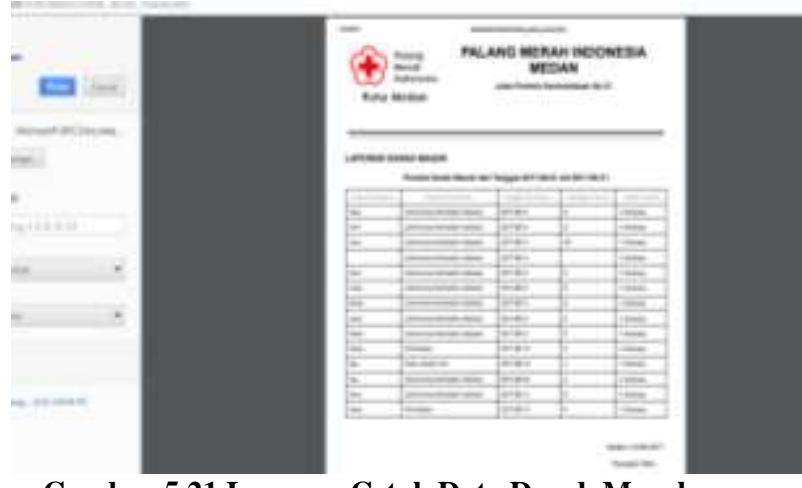

Gambar 5.21 Laporan Cetak Data Darah Masuk Berdasarkan Periode Tertentu

\section{Laporan Darah Keluar Berdasarkan Periode}

Gambar di bawah ini menampilkan laporan darah keluar berdasarkan periode tertentu. Gambar laporan darah keluar berdasarkan periode dapat dilihat pada gambar dibawah ini. 


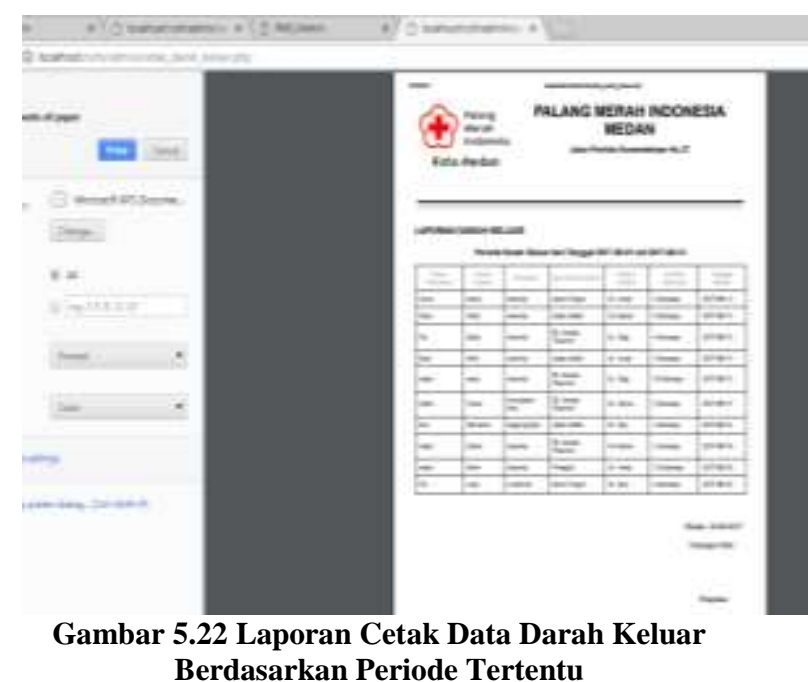

\section{KESIMPULAN DAN SARAN}

\section{A. Kesimpulan}

Dari hasil analisis terhadap percobaan implementasi sistem yang telah dilakukan dapat diambil beberapa kesimpulan mengenai analisis dan desain sistem informasi ini, yaitu:

1. Sistem yang sudah dibangun dapat mengolah data darah masuk dari pendonor dan mengolah data keluar dari permintaan darah.

2. Sistem rantai pasok yang dibangun ini dapat memudahkan PMI dalam mengatur persediaan darah karena data stok darah dapat diakses dengan mudah dari sistem yang sudah dibangun.

3. Sistem yang dibangun dapat memudahkan pemohon untuk meminta darah karena sistem yang sudah dibangun menyediakan fitur untuk mengisi data pasien yang membutuhkan tanpa harus datang ke PMI secara langsung.

4. Sistem yang dibangun dapat mencakup proses pembuatan laporan, seperti laporan darah masuk dan laporan darah keluar yang dimana laporan ini berdasarkan tanggal periode penginputan yang dimana proses laporan ini hanya bisa diakses oleh pimpinan.

\section{B. Saran}

Adapun saran dari pembuatan Sistem ini adalah

1. Dalam penerapan sistem baru ini hal yang perlu diperhatikan adalah adanya perawatan hardware dan software yang baik dan benar.

2. Sistem digunakan sebagai bahan penelitian berikutnya untuk mengembangkan program lebih lanjut.

3. Perlu diadakan pelatihan personil dalam menangani pengolahan data secara terkomputerisasi yang akan bertindak sebagai operator program, supaya proses penginputan data, record transaksi, sampai penyajian laporan dapat berjalan dengan lancar.

\section{DAFTAR PUSTAKA}

[1] Al Bahra Bin Ladjamudin .2011 Analisis Dan Desain Sistem Informasi. Graha Ilmu. Yogyakarta.

[2] Andri Adikusumah. 2015. "Perancangan Sistem Informasi SCM Produk Pertanian Berbasis Website".

[3] Afyenni, Rita. 2014. Perancangan Data Flow Diagram Untuk Sistem Informasi Sekolah (Studi Kasus Pada Sma Pembangunan Laboratorium Unp). Jurnal Teknoif - Issn 2338-2724 Vol 2, No 1 (2014): Volume 2 No 1 April 2014.

[4] Ariani, Desi., \& Dwiyanto, Bambang Munas 2013. Analisis Pengaruh Supply Chain Management Terhadap Kinerja Perusahaan. Jurnal Studi Manajemen \& Organisasi, Vol.10 No.2, Juli 2013, Hal. 132-134.

[5] Arief, M., Rudianto. 2011. Pemrograman Web Dinamis menggunakan PHP dan MySQL. C.V ANDI OFFSET. Yogyakarta.

[6] Budi Sutedjo dharma Oetomo. 2010. Perencanaan \& Pembangunan Sistem Informasi, Andi, Yogyakarta.

[7] Brady, M.,\& Loonam, J., "Exploring the use of entity-relationship diagramming as a technique to support grounded theory inquiry", Bradford: Emerald Group Publishing, 2010.

[8] Connolly, Thomas and Begg, Carolyn. (2012). Database Systems A Practical Approach to Design, Implementation, and Management Fifth Edition. Boston: Pearson Education.

[9] Elizabeth Nurmiyati Tamatjita.2015. Konsep Perancangan Logika Terstuktur Basis Data Dengan Agregasi Pada Entity Relationship Diagram (Erd). Komputer Dan Informatika \#\#Issue.Vol\#\# 7, \#\#Issue.No\#\# 1 (2006): Volume 7 No1.

[10] Jogiyanto Hm, Prof.,Dr., Mba, Akt.2012. Analisis \& Desain Sistem Informasi : Pendekatan Terstruktur Teori Dan Praktik Aplikasi Bisnis. Andi Offset. Yogyakarta.

[11] Hakimah, Maftahatulrotul. 2015. Rancang Bangun Aplikasi Peramalan Persediaan Barang Dengan Metode Trend Projection. Jurnal Simantec Vol 5, No 1 (2015).Publisher: Jurnal Simantec.

[12] Hidayatuloh, Sarip.2015. Pengembangan Aplikasi Database Kepegawaian Pada Bank Perkreditan Rakyat Syariah Harta Insan Karimah. Sistem Informasi Vol 4, No 1 (2011): Jurnal Sistem Informasi Vol.4 No.1 Februari 2011.

[13] Sumangkut, Angelia A. 2013. Kinerja Supply Chain Management Dan Strategi Informasi Pada Pt. Multi Food Manado.Jurnal Riset Ekonomi, Manajemen, Bisnis Dan Akuntansi Vol 1, No 3 (2013): Jurnal Emba, Hal 882 - 997.

[14] Sutiyadi. (2010). Promosi Efektif "Menggugah Minat \& Loyalitas Pelanggan”. Jakarta : PT. Suka Buku.

[15] Suyanto. 2007. Belajar HTML dan CSS "Tutorial fundamental dalam mempelajari HTML \& CSS" . Indonesia: Endra Abdul Hadi, A.Md.

[16] Teddy Dwiyangtri P \& Sarip Hidayatuloh.2016. Implementasi Sistem Supply Chain Management (Scm) Pada Pt. Carrefour Indonesia. Studia Informatika: Jurnal Sistem Informasi , 5(1), 2012, $1-6$. 
[17] Usada, Elisa.2014. Rancang Bangun Sistem Informasi Jadwal Perkuliahan Berbasis Jquery Mobile Dengan Menggunakan Php Dan Mysql. Journal Infotel Vol 4, No 2.

[18] Wahyuni, Dini. 2015. Pengembangan Aplikasi Situs Jejaring Sosial "Pidback!” Berbasis Bahasa Indonesia Menggunakan Bahasa Pemrograman Php Dan Mysql.Ug Journal Vol 6, No 4.

[19] Yanti Nuraeni Muflikh. 2014. A Study Of Supply Chain Management In Indonesian Modern Food Retailing Chains For Fresh Vegetable (Case Study: Farm Producer Company, Pt. Saung Mirwan, Bogor, Indonesia). Jurnal Agribisnis Dan Ekonomi Pertanian (Volume 2. No 1).

[20] Yuhendra, 2015, “Jurnal Rekayasa Perangkat Lunak Pengolahan Data Distribusi Obat-Obatan Di PT. Anugrah Pharmindo Lestari Berbasis Web". 